\title{
Cruzando fronteiras
}

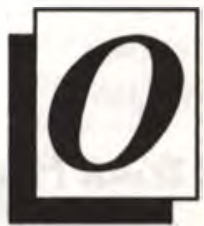

expressivo múmero de migrantes que deixaram o Brasil nos últimos anos, vem colocar uma série de questões relevantes para um pais que em décadas anteriores era então considerado o pais do futuro, passando a ser mais um entre outros a exportar o que possui de mais de suas vidas.

precioso, que é a sua força de trabalho no momento mais produtivo

Em primeiro lugar, é preciso explicitar que tal fenômeno não é um fato isolado que afeta apenas alguns paises, sobretudo os mais pobres, mas que cada vez mais tais movimentos migratórios adquirem uma tal magnitude e complexidade, envolvendo a todos em um processo que tende a assumir dimensões sempre mais interdependentes e globalizadoras. Neste sentido, as abordagens do fenômeno passam a incorporar perspectivas cada vez mais amplas, considerando-se os vários fatores que permeiam os movimentos migratórios no mundo moderno, tais como fatores macroestruturais, culturais, étnicos, religiosos, etc.

Assim sendo, neste número de Travessia, vários pesquisadores assumem o desafio de abordar a questão da emigração a partir de vários enfoques, discutindo os diversos aspectos que estes fluxos apresentam, como o perfil sócio-cultural dos que emigram, a sua ambigua inserção no mercado de trabalho dos paises receptores, ocupando postos de trabalho muito aquém de suas qualificações, como também os significados que a emigração representa para muitos como uma forma de conquistar a tão desejada mobilidade social e de resistir ao processo de ruptura com as suas raizes.

Dentro do amplo espectro que a emigração apresenta atualmente, destacamos o fluxo de brasileiros para os Estados Unidos, Europa, Japão e países limitrofes sul-americanos, como também o caso dos portugueses e cubanos.

Certamente o esforço e a riqueza das análises que ora apresentamos não esgotam a complexidade de tão ampla problemática, mas vêm sem dívida alguma estimular novos estudos, ampliando o debate sobre as razões pelas quais emigrar representa uma saida para milhões de pessoas no mundo, ainda que tenham que pagar um preço por isso.

Sidmey da Silva 